Article

\title{
Rethinking Design and Urban Planning for the Cities of the Future
}

\author{
Thomas L. Saaty ${ }^{1}$ and Pierfrancesco De Paola ${ }^{2, *}$ \\ 1 Joseph M. Katz Graduate School of Business, College of Business, University of Pittsburg, Mervis Hall 322, \\ Pittsburg, PA 15260, USA; saaty@katz.pitt.edu \\ 2 Department of Industrial Engineering, University of Naples Federico II, Piazzale Vincenzo Tecchio 80, \\ 80125 Napoli, Italy \\ * Correspondence: pierfrancesco.depaola@unina.it; Tel.: +39-320-66-11-888
}

Received: 13 June 2017; Accepted: 22 August 2017; Published: 24 August 2017

\begin{abstract}
Growth of urban areas and abandonment of rural areas are phenomena that increase quickly. The main consequences of urbanization are pollution, consumption of resources and energy, waste dumps, and junk yards. These aspects require a better planning and design of European urban metropolitan areas, considering benefits, opportunities, costs and risks (B.O.C.R.), derivable by urban transformations and available resources. The paper consists of five parts. The first part contains some reflections on consequences of urban sprawl. In the second part, some possible kinds of cities are discussed (sustainable city, smart city, and compact city). The third part briefly describes a multicriteria decision-making approach known as the 'analytic hierarchy process' to deal with complex decisions. In the fourth part, alternative city models are analyzed (compact city, elevated city, green house city, and water city). Finally, in the fifth part, the criteria selected for the planning and design of the alternative city models are used for the prioritization of some European cities.
\end{abstract}

Keywords: planning; design and urban transformations; analytic hierarchy process (AHP); analytic network process (ANP); B.O.C.R. model; compact city; European cities

\section{Introduction}

Evolution of cities needs to guarantee the continuity of living activities (internal and external) and to avoid nature's control over populations, mostly from effects of increasing climate change on Earth [1]. This is a main objective for the future of European cities.

Decisions about where and how to live depend, primarily, by particular conditions and circumstances. If people live in open spaces, it is plausible that they tend to prefer open spaces in their future, and it is hard and strange to think that they will live in close neighborhoods (unless specific privileges are present that can compensate for existing differences between open and close spaces). For example, for the city of Naples (the Neapolitan conurbation counts a population of about 4 million) it has been demonstrated that a key role for residential location choices is the "sense of belonging" to neighborhoods where people grew up since they were children [2].

Growth of urban areas and abandonment of rural areas are phenomena that increase quickly, in contrast with the slow decline of the European population. Another significant aspect that involves the European population is an increasing gap between the elderly population and children, the phenomenon of population ageing means more care is needed in the planning of future investments for resource allocation (particularly in social services). Moreover, the migration of people from countries in war towards Europe will drive cities' urbanization at a much higher rate. For these reasons, private corporations, international agencies, and local governments base their decisions on demographic projections and, consequently, plan their strategies and investments. 
All these issues create a need for better planning and design of European urban metropolitan areas, considering all benefits, opportunities, costs, and risks (B.O.C.R. model) derivable by urban transformations and available resources.

This paper attempts to update ideas of urban design in a holistic way and also shows how to apply modern theories of decision making to make rational choices in building cities.

With these basic goals, the paper describes various possibilities of future cities considering the various constraints and demands of society, the environment, and geography. The future city project aims to delve into details of various future city models and aims to find out which model will be best suitable depending upon the strategic criteria usable to evaluate the various merits of the B.O.C.R. model. The four alternative kinds of cities analyzed according to their merits are: compact city, elevated city, green house city and water city. At the same time, we identify the main criteria for the process of designing and selecting different kinds of cities we think are plausible for the future of European citizens. We then use these criteria to demonstrate how we can prioritize alternative European cities.

The paper consists of five parts. The first part contains some reflections on consequences of urban sprawl. In the second part, some possible kinds of cities are discussed (sustainable city, smart city, and compact city). The third part briefly describes a multicriteria decision making approach known as the analytic hierarchy process to deal with complex decisions. In the fourth part, alternative city models are analyzed (compact city, elevated city, green house city, water city). Finally, in the fifth part, the criteria selected for the planning and design of the alternative city models are used for the prioritization of some European cities.

\section{Consequences of Urban Sprawl}

The main consequences of urban sprawl are pollution, consumption of resources and energy, waste dumps, and junk yards. These aspects request a better planning and design of European urban metropolitan areas.

Landscape evolution and ecosystem transformations are driven by urbanization processes, further exacerbated by fast growing urban population that might increase the risks of environmental problems. Inappropriate land use is recognized as one of the most important anthropogenic influences on global climate change, this is because strong relationships exist between population, environment, development, and land use [1].

McKinsey Global Institution grouped the urbanization pressures into four main categories [3]: land and spatial development; primary resources request and pollution; labor and skills; funding.

According to some of the most recent reports of Greenpeace and the Intergovernmental Panel on Climate Change (I.P.C.C.), the global average surface temperature increased by $0.74{ }^{\circ} \mathrm{C}$ during the period 1906-2005, mainly for the consequences of anthropic activities [4,5]. Global climate changes will have unpredictable impacts on ecosystems. Related to this problem, land-use decisional processes and infrastructure investments need to reduce the vulnerability and to enhance the opportunities for European urban populations. A particular environmental impact on cities induced by urbanization is the so-called 'urban heat island' effect: due to higher solar radiation absorption and greater thermal capacity and conductivity in urban areas, the heat is stored during the day and released the night (with higher temperatures for urban areas respect to rural areas).

Urbanization processes have generated metropolitan areas with urban systems heterogeneous for many aspects (real estate values, demography, environmental and socio-economical factors, building types, imperfect real estate markets, etc.) [6-12], with different ways to reply to climate and environmental changes.

If urban living is rising, many big cities' social and cultural amenities are not easily accessible to their populations. Every city should be like a creativity arena with multidimensional activities, where people's talents grow and dreams materialize. It should also be noted that cities have a large number of people who must adapt to urban life without skills necessary to a real adaption: crime can be born from this conflict. 
However, urban population increase may also have its advantages: in some cases, the cities concentrate poverty, but in other cases cities also provide the most important escape from poverty at the same time. Modern civilization can damage resources and ecosystems, but cities also have great potentialities for the long-term sustainability. If cities generate problems, they already include possible solutions too. Therefore, urbanization's benefits are potentially higher than its disadvantages, but problems and opportunities are key points for improving urban life, for long-term growth and for environmental and social sustainability.

The strategies to improve the future of urban life cannot be prescind the participation of civil society in the processes of design and urban planning. Only a holistic management of cities may be a possible solution to truly maximize the economic benefits of local communities [1].

\section{Sustainable city, Smart City, Compact City}

Almost $80 \%$ of Europe's population lives and works in urban areas. In response to the growing housing emergencies, the Joint Programming Initiative (JPI) of European Commission (EC) promotes new development dynamics and new design strategies, encouraging systemic approaches in the ability to maximize possible benefits by advanced technologies also considering their socio-economic impacts $[13,14]$.

According to Wikipedia's definition, a sustainable city is "a city designed with consideration of environmental impact, inhabited by people dedicated to minimization of required inputs of energy, water and food, and waste output of heat, air pollution- $\mathrm{CO}_{2}$, methane, and water pollution" [15].

In the literature, some works identify the compact city model as an effective sustainable urban form [16-18].

In the 90s Basiago studied how to make cities sustainable and concluded by suggesting 15 general principles for sustainable urbanization [19]:

- a sustainable city is a garden city that integrates town and country [20];

- a sustainable city possesses the vital form of the medieval city [21];

- a sustainable city has a form nearest to organic as possible [22];

- a sustainable city elevates maternal, life nurturing functions [23,24];

- a sustainable city is designed with nature [25];

- a sustainable city is a permaculture [26];

- a sustainable city features solar design, natural drainage, edible landscape [27];

- a sustainable city is compact and regenerative of damaged or derelict urban land [28];

- a sustainable city is made compact to allow surrounding wilderness to flourish [29];

- a sustainable city has a circular metabolism [30];

- a sustainable city makes no waste, seeks biodiversity, relies on the sun [31];

- $\quad$ a sustainable city does not exceed nature's carrying capacity [32];

- a sustainable city uses transit oriented development to control growth [33];

- a sustainable city is holistic, diverse, fractal, and evolutionary [34];

- a sustainable city is comprised of green infrastructure [35]

Moreover, Basiago said that sustainable land use requires the addressing of three specific issues by local governments [19]:

- to find optimal sites for urban and industrial activities;

- financial systems must adopt the cost accounting system of nature;

- sustainable buildings are the basic unit of urbanization.

Concerning the above requirements, in recent years Copenhagen was declared like the most eco-friendly city from many European institutions, but according to Arcadis report on "Sustainable 
Cities Index 2016" [36], Copenhagen is really only in the 12th European position of sustainable cities (\#14 world ranking), where the 10 most sustainable European cities are: Zurich (no.1 world ranking), Stockholm (no.3 world ranking), Vienna (no.4 world ranking), London (no.5 world ranking), Frankfurt (no.6 world ranking), Hamburg (no. 8 world ranking), Prague (no. 9 world ranking), Munich (no.10 world ranking), Amsterdam (no.11 world ranking), and Geneva (no.12 world ranking). In the world ranking, the first 15 sustainable cities are all European with the exception of Singapore (no. 2 world ranking) and Seoul (no.7 world ranking).

Different from the concept of a sustainable city, a smart city aims to deploy advanced technology solutions, synergistically interconnected, for different infrastructures and urban activities: services, business, transport, communication, water, and energy. However, cities are really smart when new advanced technologies are able to optimize the use of limited resources and core systems.

Theoretically, smart cities could represent the right way for a sustainable prosperity of cities, but this can only be done through revolutionary and not evolutionary urban changes.

Cohen Boyd, a climate strategist helping to lead companies, communities, and cities towards a low carbon economy, structured the so-called "Smart Cities Wheel" (see Figure 1) [37].

According to "Cities in Motion Index 2016" provided by IESE Center for Globalization and Strategy-University of Navarra, published by Forbes [38], the top 10 smartest European cities are: London (no.2 world ranking), Paris (no.3 world ranking), Amsterdam (no.6 world ranking), Geneva (no. 9 world ranking), Copenhagen (no.11 world ranking), Zurich (no.14 world ranking), Berlin (no.16 world ranking), Munich (no.21 world ranking), Helsinki (no. 25 world ranking), and Vienna (no.26 world ranking). In the world ranking only 10 cities are European among the first 30 (New York, NY, USA is at the no.1 world ranking).

With reference to compact cities, it should be noted that the term "compact city" was coined firstly in 1973 by George Dantzig and Thomas L. Saaty, whose utopian vision was widely driven by a desire to see a more efficient use of resources and better survival conditions for people [39].

Sometimes in distorted way, the compact city was strictly intended by some urban planners like an urban development plan seeking to eliminate the urban sprawl and emphasize the sustainability.

In the original vision of Dantzig and Saaty the Compact City would be an economic city to build and maintain, with many green spaces like public parks or private gardens. The travel time from home to schools or work places would be very short, with the possibility to choose the most desirable travel modality (walk, bicycle, or public transport services). Stores, restaurants, delivery services, health facilities, and all routine services would always be fully available. In the compact city, there would be no urban sprawl, freeways, traffic, smog, pollution, and other urban annoyances. With building construction costs flexible so that it would be easy to remodel, renew, and rearrange parts of the city, avoiding the processes of urban decay. The compact city would be divided into five circular areas, more precisely from inside to outside: the core (work's area with offices, shops, schools, public services, etc.), core edge, inner residential area (with particular regard to vertical dimension), mid-plaza (local facilities, elementary schools for children, clinics, neighborhood shops, parks, and play areas), outer residential area. The compact city would be a four-dimensional city: most of cities are predominantly two-dimensional cities, but the compact city would have the time as a further dimension, over building upwards (third dimension) [39].

General requirements and preferences about a well-designed compact city should include the following multiple goals: aesthetic environment; many labor-saving conveniences as possible; fast access to any part of the city; suitable climate; low-cost living; conservation of agricultural land; easy access to natural surroundings; elimination of delays; reduced pollution; elimination of accidents; prevention of sabotage; maximizing escape possibility in case of natural disasters.

A study by Arifwidodo and Perera [40] has posed a relevant research question: if implementing the policies on a compact city would significantly improve the quality of life of its residents. The mentioned study, applied on the city of Bandung, did not provide a definite answer (Bandung is a city of Indonesia with about 5.9 million of people in its metropolitan area, population density is about 14.975 people 
per kilometer). Although the results of the study cannot be generalized, the authors argue that the results seem to suggest that the policies of a compact city, applicable in developed countries, may not be easily applicable to cities in developing countries: the cities in developing countries may have more problems in managing the impacts derived from intense urban development.

The Eco-Compact City Network (E.C.C.N.) detects some kinds of "Eco-Compact Cities" (cities developed in balance with the natural environment, with optimum population density, with an extended system of small retails, efficient public transportation systems, pedestrian-friendly cities), many of these cities are located in Spain [41]: Paris (France); Gijon, Salamanca, Burgos, Bilbao, San Sebastian, Vitoria (Spain); Brandevoort (a new town in Netherlands, designed by Rob Krier and Christoph Kohl, with a population density of 0.05 hab./sqkm).

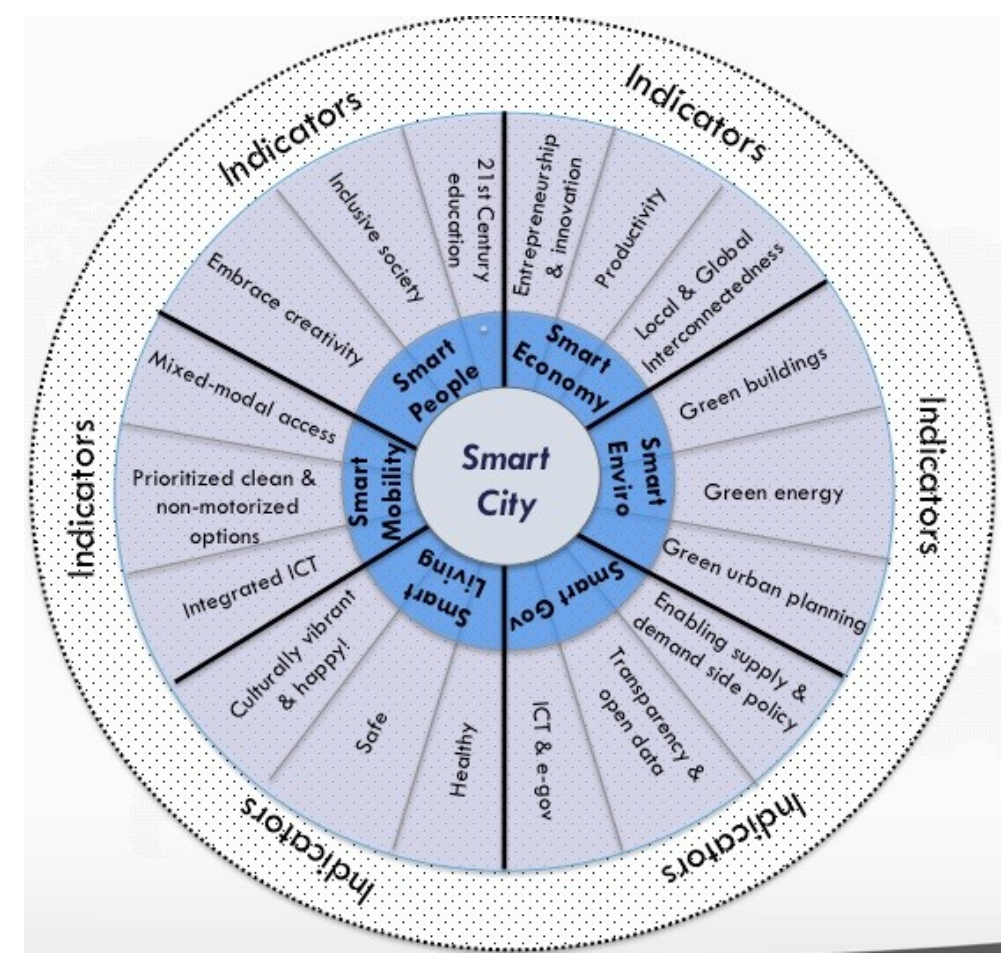

Figure 1. Smart cities wheel of Cohen Boyd (source: [37]).

\section{Sustainability and Multicriteria Decision Making}

Measuring the sustainability in urban areas is a challenge for environmental managers and decision-makers. The idea of sustainable urban development was formulated in order to meet the growing understanding regarding the several strategic relationships between: different urban processes with reference to social and economic development; global, regional, and local environmental problems; increase of urban population; urban sprawl.

The analytic hierarchy process is a valid tool for evaluating the urban sustainable development. This because the evolution of cities leads to the need to develop options of innovative designs or policies that would be beneficial for improving current conditions and providing with opportunities to take advantage for future benefits. At the same time, we need to consider their cost and risk consequences too. We can choose the best designs or policies by considering all the benefits-opportunities-costs-risks (B.O.C.R.) factors in a holistic manner.

The analytic hierarchy process, a theory for priority measurement for design and evaluation, created and developed by one of these authors [42-45], is a way to make complex decisions involving feedback, and can be used to help with the many decisions and evaluations we need to make as we design future cities [46-52]. 
We need not only to identify the B.O.C.R. elements, but also to understand interdependence among them and how the elements dominate each other to finally influence the outcome of our decision problem. Working with a group of elements adds challenges but is inevitable to synthesize the diversity of knowledge and to deal with the difference in preferences.

The set of potential outcomes and the alternatives from which to choose are the essence of decision making. In laying out the framework for making a decision, one needs to sort the elements into groupings or clusters that have similar influences or effects. One must also arrange them in some rational order to trace the outcome of these influences. Briefly, the decision making is a process that involves the following steps:

- understand and define the problem as completely as possible;

- structure a problem with a model that shows the problem's key elements and their relationships;

- elicit judgments that reflect knowledge, feelings, or emotions;

- represent those judgments with meaningful numbers;

- use these numbers to calculate the priorities of the elements of the hierarchy;

- $\quad$ synthesize these results to determine an overall outcome;

- analyze sensitivity to changes in judgment.

Cities can be seen as complex networks of components: citizens, businesses, transports, communications, water, energy, urban integrated services, and other systems. Understanding how activities improve and change through the lens of these elements offers cities new perspectives on the progress they are making toward implementing their strategies for achieving their objectives.

Starting from the analytic hierarchy process (AHP) and its generalization to dependence and feedback, the analytic network process (ANP) comprise a well-known methodology that has been widely used for making the same kind of complex decisions needed here for choosing among the kind of cities to build, their design, location, and all the nuances involved in trading off different characteristics.

The AHP is about breaking a problem down, prioritizing all the factors, and then aggregating the solutions of all the sub-problems into a conclusion. It facilitates decision making by organizing perceptions, feelings, judgments, and memories into a framework that identifies and exhibits the forces that influence a decision. The connections between the factors that go into making a decision have two kinds of structures. The first is hierarchic descending from a goal to criteria, subcriteria, then down to a level of alternatives that need ranking to determine the best choice (AHP). The other kind of structure is a network with interdependences and feedback (ANP).

Substantially, an ANP decision model is a more general structure that allows connections in other ways than the top-down ones in a hierarchy. An ANP model is better for capturing the complexity of the real problems.

Paired comparisons are the first fundamental paradigmatic shift of the AHP in conceptualizing how the mind works to generate judgments or to expression of the sense of relative priority and order. Judgments are inherently subjective, involving both tangible and intangible qualities. The AHP applies relative measurement, the only way to measure intangible qualities or understanding.

Consequently, to construct a measurement theory that would be applicable for complex problems, a new scale had to be invented to represent relative judgments. To make a judgment on a pair of elements on should begin by perceiving which is the dominant element in the pair to be judged, then select a verbal expression from the following statements that best expresses how dominant it is.

Moreover, we generally need to compare more than a pair of objects, which calls for converting the verbal judgments into numbers so that they can be synthesized to derive their relative measurement. Pursuing the accuracy of their representation demands that they need to be validated when measurements exist to enhance the belief that accurate outcomes can also be reaches by experts when applying judgment to compare intangibles qualities. 
The AHP uses the integers 1 to 9 as its fundamental scale of absolute numbers corresponding to the verbal statements for the comparisons. This scale is not an arbitrarily chosen set of ordinal numbers but is a meticulously derived scale of absolute numbers by using stimulus-response theory in psychology [42-45]:

- 1 Equal importance;

- 3 Moderate importance of one over another;

- 5 Strong or essential importance;

- 7 Very strong or demonstrated importance;

- 9 Extreme importance;

- 2, 4, 6, 8 Intermediate values.

Use reciprocals for inverse comparisons.

\section{The Best City Model for the Future}

Mainly, there are possible kinds of compact city, and more precisely [1]:

- Circular compact city. The main goal behind the compact circular city is to take advantage of its specific circular design, because all points at the circumference are equally distant from the center. The central part of a circular city would be mainly reserved for residential units (apartment dwellings and community housing). If housing units are at the center, there would be better security for the residents with good mutual social relations. Infrastructures would be placed around the center. The outermost levels should be reserved for industrial structures (minimizing environmental pollution). On the top of buildings there would be green parks as roofs, while city would be surrounded by rural countryside (without suburbs). The major benefits of the circular compact city are less city congestion and efficient public transport systems. However, its main limitation is the poor space for further expansion, even if a network of compact circular cities would be a possible way to resolve the urban expansion problem.

- Elevated city. The main goal of the elevated city is the preservation of natural landscapes. The nature would be raised to preserve the environmental contexts. Ecological efficiency would be the main rule, using recycled building materials, compost toilets, nature-based water cleansing systems, forests, plant life, and water-based ecosystems. Essentially, the elevated city would be more an ecosystems design than an architectural habitation design. Nature's beauty would be preserved by condensing living areas, working environments, commercial, and industrial services, into an upwardly directed architectural structure. The ideal form of the elevated city is the trumpet bell shape, with high compressive characteristics. The city would be completely self-sufficient in terms of energy, energy entirely produced from renewable sources.

- Green house city. The main goal of this city is the use of natural forms and resources to build future houses. The idea of the green house city is to build houses only with wood materials. Transportation would be only by vehicles powered with bio-fuels. The use of fossil or natural resources such as coal, oil, and gas would be minimal and restricted. Green houses have many advantages, however these houses would be not adaptable where climate conditions are unfavorable, where trees/wood are not available easily, and it is also necessary to consider the limited useful life of wood materials. Although the green houses may not be able to provide all the comforts as apartments, the green house city is a realistic possible model for the cities of the future.

- Water city. This kind of city would be a complex system of structures in able to accommodate many people and to relieve population's pressures on land. New synthetic materials could be used for buildings, to withstand the corrosive effects of the harsh water environment. This is a conceptual view of a city and, in effect, a similar construction could be the Palm Island located in the sea of Dubai. 
Although in recent years many studies have been carried out on the topic of 'compact cities', its distinction into the four models described above can still be considered current.

Now we use an ANP model to rank them in order to choose the best one. In particular, a complex B.O.C.R. model is implemented with separate models used for analyzing benefits, opportunities, costs, and risks.

Paired comparisons and analytic elaborations are carried out with Super Decisions software (free available, after registration, at www.superdecisions.com).

Figure 2 shows the general structure of the ANP model used to combine the results from the separate B.O.C.R. models. It contains the strategic criteria used to evaluate the importance of the B.O.C.R. nodes, the priorities of which are then used to combine results from the separate B.O.C.R. models to give the best overall answer. The priorities of the B.O.C.R. nodes are multiplied by their respective vectors of priorities of the cities and combined to determine the overall importance of the cities. The strategic criteria are invariant higher-level concerns that must be considered in every decision and are used to evaluate the priorities of the B.O.C.R. nodes in the particular decision: basic necessities, environmental friendliness, population pressure, social life, and social care.

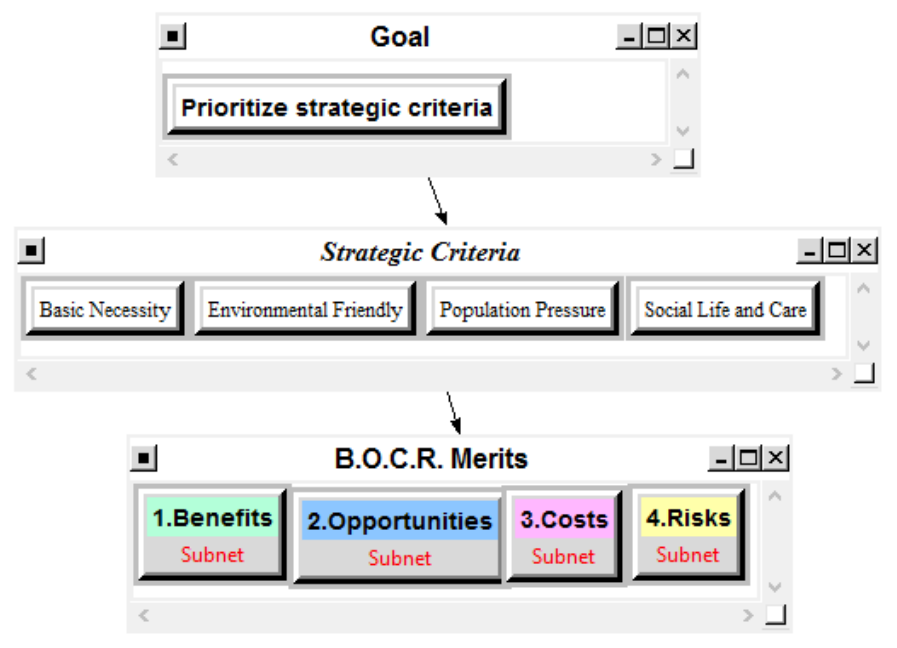

Figure 2. Main structure of ANP model provided by Super Decisions software.

The control criteria for the benefits subnet, opportunities subnet, costs subnet, and risks subnet are shown in Tables 1-4. For every control criterion further subnets exist with a subsequent priority order of alternatives. Tables 1-4 show all clusters and elements for the separate B.O.C.R. models.

\section{Benefits model}

- Social subnet. Social benefits judge future cities on the quality and availability of public services, medical facilities, city energy demand, housing needs related to the increase of population, travel expenses. For this subnet, the element 'time spent with family' has the highest global priority (see Table 1).

- Environmental subnet. Environmental benefits are expressed by following parameters: energy conservation, and impacts on flora and fauna, pressure on natural resources consumption, low environmental pollution. For this subnet, the element 'water' has the highest global priority (see Table 1).

- Economic subnet. Economic benefits are expressed by following parameters: low living expenses, infrastructures development and their maintenance, transportation costs and costs related to development of new parking spaces. For this subnet, the element 'income' has the highest global priority (see Table 1). 
- For the benefits model, the compact city and the water city have more benefits and they are aligned on the same value substantially, with the first city being slightly higher than the second (0.311 vs. 0.310 , see Table 5).

\section{Opportunities model}

- Social subnet. Social opportunities deriving by the cities of the future are expressed by following parameters: free time opportunities, low crime rate, work-life balance, and social harmony. For this subnet, the element 'work-life balance' has the highest global priority (see Table 2).

- Technological subnet. Technological opportunities deriving by the cities of the future are expressed through the sharing of technical advances with the subsequent impacts on overall life aspects. For this subnet, the element 'technical advances' has the highest global priority (see Table 2).

- Economic subnet. Economic opportunities are expressed by following parameters: job creation opportunities related to the increase of population, opportunities linked to the increased budget for security and public health. For this subnet, the element 'health budget' has the highest global priority (see Table 2).

- For the opportunities model, the compact city presents the greatest opportunities followed by the green house city (see Table 5).

\section{Costs model}

- Environmental subnet. Environmental costs are expressed by following parameters: climate changes, impacts on flora and fauna, waste management. For this subnet, the element 'climate changes' has the highest global priority (see Table 3).

- Financial subnet. Financial costs are expressed by following parameters: loss of existing investments, complexity of processes, raw materials costs, waste disposal problems, development, and city maintenance costs. For this subnet, the element 'waste disposal' has the highest global priority (see Table 3).

- Social subnet. Social costs are expressed by following parameters: costs for maintain law \& order in the city, acceptance costs of available alternatives, historical and cultural heritage loss. For this subnet, the element 'law and order' has the highest global priority (see Table 3).

- For the costs model, the water city presents the highest costs followed by the green house city (see Table 5).

\section{Risks model}

- Technology subnet. Technological risks are expressed by following parameters: technology support and improvement for the increase of population, dead-end risk due to technological changes, technology misuses, and uncertainties in the technological feasibility. For this subnet, the element 'technology support' has the highest global priority (see Table 4).

- Environmental subnet. Environmental risks are expressed by following parameters: lives and properties losses due to natural disasters or unknown risks for human health and environmental threats to flora and fauna. For this subnet, the element 'disaster threats' has the highest global priority (see Table 4).

- Financial subnet. Financial risks are expressed by following parameters: affordability, adaptability, and sustainability of the city, in addition to potential unexpected expenses for the maintenance of public services. For this subnet, the element 'self sustainable' has the highest global priority (see Table 4).

- Social subnet. Social risks are expressed by following parameters: basic support by society, isolation from neighbors and loved ones, crime rate. For this subnet the element 'crime rate' has the highest global priority (see Table 4).

- For the risks model, the water city presents the highest risks in absolute (see Table 5). 
In Table 5, the overall output about the best city model of the future is reported.

Figure 3 shows the synthesizing results using multiplicative formula of the B.O.C.R. model $\mathrm{m}$, this option is the best solution in the short-term [1]. More in detail, in the short-term scenario, the overall synthesized priorities for the alternatives are reported in Figure 3. The results highlight that the compact city is, in absolute, the preferred alternative for the city of the future in the short-term.

Figure 4 shows the synthesizing results using additive method of the B.O.C.R. model. The additive method combines the priorities $(b, o, c, r)$ and the strategic criteria $(B, O, C, R)$ as follows: $[(b \times B)+(o \times O)-(c \times C)-(r \times R)]$; this option is the best long-term alternative [1]. More in detail, in the long-term scenario, the overall synthesized priorities for the alternatives are reported in Figure 4. Also in this case, the results highlight that the compact city is the preferred alternative in the long-term for the cities of the future. The only other alternative is the green house city.

Finally, a sensitivity analysis has carried out for to verify the variance of overall results for a specific input parameter (varying the 50\% weight for benefits, opportunities, costs and risks; see Figure 5). According to sensitivity analysis, in the short-term the compact city is always the best alternative followed by the green house city.

Table 1. Priorities of elements in benefits model.

\begin{tabular}{|c|c|c|c|c|}
\hline \multicolumn{5}{|c|}{ Benefits } \\
\hline Control Criteria & Clusters & Elements & Local Priorities & Global Priorities \\
\hline \multirow{10}{*}{ Social (0.31) } & \multirow{2}{*}{ Administrative (0.15) } & Security & 0.747 & 0.035 \\
\hline & & Public services & 0.253 & 0.012 \\
\hline & \multirow{2}{*}{ Medical (0.35) } & Availability & 0.474 & 0.051 \\
\hline & & Quality & 0.526 & 0.057 \\
\hline & \multirow{3}{*}{ Quality of life (0.42) } & Energy needs & 0.216 & 0.028 \\
\hline & & Housing & 0.264 & 0.043 \\
\hline & & Time spent with family & 0.520 & 0.068 \\
\hline & \multirow{3}{*}{ Government (0.08) } & Policy executive & 0.255 & 0.006 \\
\hline & & Policy planning & 0.270 & 0.007 \\
\hline & & $\begin{array}{l}\text { Public welfare } \\
\text { department }\end{array}$ & 0.475 & 0.012 \\
\hline \multirow{8}{*}{$\begin{array}{c}\text { Environmental } \\
(0.49)\end{array}$} & \multirow{5}{*}{ Stakeholder (0.80) } & Air & 0.176 & 0.069 \\
\hline & & Energy & 0.159 & 0.062 \\
\hline & & Flora and fauna & 0.183 & 0.072 \\
\hline & & Land & 0.165 & 0.065 \\
\hline & & Water & 0.317 & 0.124 \\
\hline & \multirow{3}{*}{ Other $(0.20)$} & Conservation & 0.668 & 0.065 \\
\hline & & Enrichment & 0.215 & 0.021 \\
\hline & & Pollution & 0.117 & 0.011 \\
\hline \multirow{11}{*}{ Economic (0.20) } & \multirow{2}{*}{ Industrialization (0.30) } & $\begin{array}{l}\text { Infrastructure } \\
\text { development }\end{array}$ & 0.724 & 0.043 \\
\hline & & Jobs & 0.276 & 0.017 \\
\hline & \multirow{2}{*}{ Administrative (0.15) } & Maintenance & 0.588 & 0.018 \\
\hline & & Security & 0.412 & 0.012 \\
\hline & \multirow{2}{*}{ Individual (0.37) } & Income & 0.711 & 0.053 \\
\hline & & Living expenses & 0.289 & 0.021 \\
\hline & \multirow{5}{*}{ Transportation $(0.18)$} & Accident & 0.441 & 0.012 \\
\hline & & Gasoline & 0.156 & 0.005 \\
\hline & & Parking & 0.104 & 0.003 \\
\hline & & Road & 0.233 & 0.007 \\
\hline & & Vehicle & 0.066 & 0.001 \\
\hline
\end{tabular}


Table 2. Priorities of elements in opportunities model.

\begin{tabular}{|c|c|c|c|c|}
\hline \multicolumn{5}{|c|}{ Opportunities } \\
\hline Control Criteria & Clusters & Elements & Local Priorities & Global Priorities \\
\hline \multirow{4}{*}{ Economic (0.44) } & \multirow{4}{*}{ Other (1.00) } & Consulting & 0.082 & 0.036 \\
\hline & & Health budget & 0.477 & 0.210 \\
\hline & & Job & 0.273 & 0.120 \\
\hline & & Security budget & 0.168 & 0.074 \\
\hline \multirow{6}{*}{ Social (0.39) } & \multirow{6}{*}{ Other (1.00) } & Crime rate & 0.217 & 0.085 \\
\hline & & $\begin{array}{l}\text { Custom and } \\
\text { tradition }\end{array}$ & 0.147 & 0.057 \\
\hline & & Health and leisure & 0.213 & 0.083 \\
\hline & & Shared community & 0.087 & 0.034 \\
\hline & & Social harmony & 0.093 & 0.036 \\
\hline & & Work life balance & 0.243 & 0.095 \\
\hline \multirow{3}{*}{ Technological (0.17) } & \multirow{3}{*}{ Other (1.00) } & Better forecasting & 0.240 & 0.041 \\
\hline & & Technical advances & 0.438 & 0.074 \\
\hline & & Technology sharing & 0.322 & 0.055 \\
\hline
\end{tabular}

Table 3. Priorities of elements in costs model.

\begin{tabular}{|c|c|c|c|c|}
\hline \multicolumn{5}{|c|}{ Costs } \\
\hline Control Criteria & Clusters & Elements & Local Priorities & Global Priorities \\
\hline \multirow{4}{*}{ Social (0.23) } & \multirow{4}{*}{ Other (1.00) } & Acceptance & 0.184 & 0.042 \\
\hline & & Heritage & 0.360 & 0.083 \\
\hline & & Law and order & 0.268 & 0.062 \\
\hline & & Social relations & 0.188 & 0.043 \\
\hline \multirow{10}{*}{ Financial (0.18) } & \multirow{3}{*}{$\begin{array}{l}\text { Administrative } \\
(0.20)\end{array}$} & Legal & 0.137 & 0.005 \\
\hline & & Loss of productivity & 0.269 & 0.010 \\
\hline & & Process Implementation & 0.594 & 0.021 \\
\hline & \multirow{7}{*}{ Other $(0.80)$} & Demolition & 0.041 & 0.006 \\
\hline & & Development & 0.131 & 0.018 \\
\hline & & Loss of investments & 0.133 & 0.019 \\
\hline & & Maintenance & 0.211 & 0.030 \\
\hline & & Raw material & 0.201 & 0.029 \\
\hline & & Training & 0.055 & 0.008 \\
\hline & & Waste disposal & 0.228 & 0.033 \\
\hline \multirow{3}{*}{$\begin{array}{c}\text { Environmental } \\
(0.59)\end{array}$} & \multirow{3}{*}{ Other (1.00) } & Waste management & 0.206 & 0.121 \\
\hline & & Climate change & 0.696 & 0.411 \\
\hline & & Flora and fauna impact & 0.098 & 0.059 \\
\hline
\end{tabular}

Table 4. Priorities of elements in risks model.

\begin{tabular}{ccccc}
\hline & & Risks & & \\
\hline Control Criteria & Clusters & Elements & Local Priorities & Global Priorities \\
\hline \multirow{2}{*}{ Social (0.34) } & & Acceptance risks & 0.079 & 0.027 \\
& Others (1.00) & Basic need support & 0.350 & 0.119 \\
& & Crime rate & 0.424 & 0.144 \\
& Stakeholder (0.25) & Seclusion & 0.147 & 0.050 \\
\cline { 2 - 5 } Financial (0.11) & & Government & 0.433 & 0.016 \\
& & Public & 0.567 & 0.018 \\
& Acceptability (0.75) & Adaptability & 0.216 & 0.014 \\
Environmental & & Affordability & 0.173 & 0.016 \\
(0.52) & & Self freedom & 0.197 & 0.034 \\
\hline \multirow{2}{*}{ Technology (0.03) } & Other (1.00) & Self sustainable & 0.414 & 0.315 \\
& & Disaster threats & 0.606 & 0.076 \\
& & Flora and fauna & 0.146 & 0.129 \\
\hline
\end{tabular}


Table 5. Overall output about the best city model of the future.

\begin{tabular}{ccccc}
\hline City Model & Benefits & Opportunities & Costs & Risks \\
\hline Compact city & 0.311 & 0.407 & 0.189 & 0.242 \\
Elevated city & 0.100 & 0.110 & 0.147 & 0.148 \\
Green house city & 0.279 & 0.268 & 0.273 & 0.240 \\
Water city & 0.310 & 0.215 & 0.391 & 0.370 \\
\hline
\end{tabular}

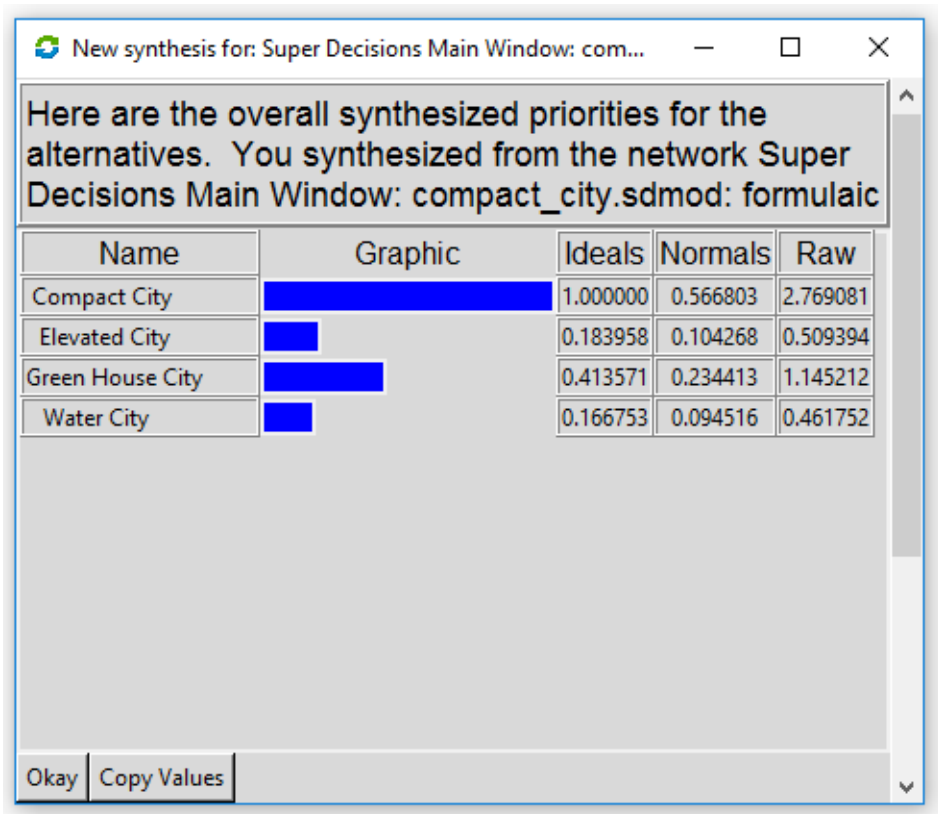

Figure 3. B.O.C.R. model: best city in the short-term (multiplicative formula).

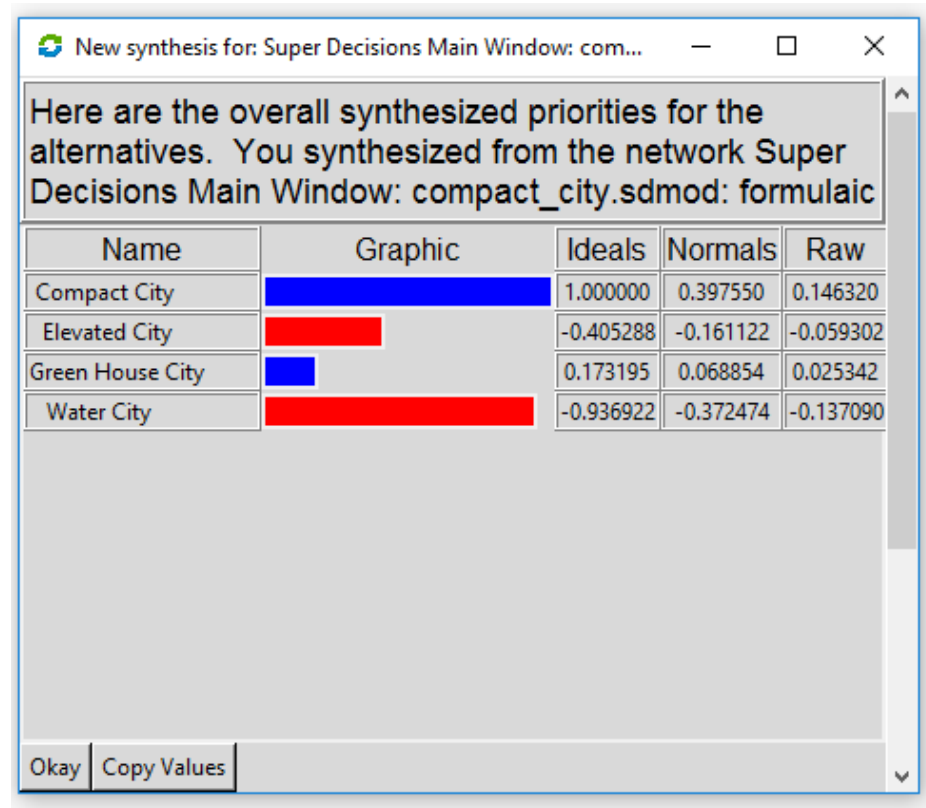

Figure 4. B.O.C.R. model: best city in the long-term (additive formula). 


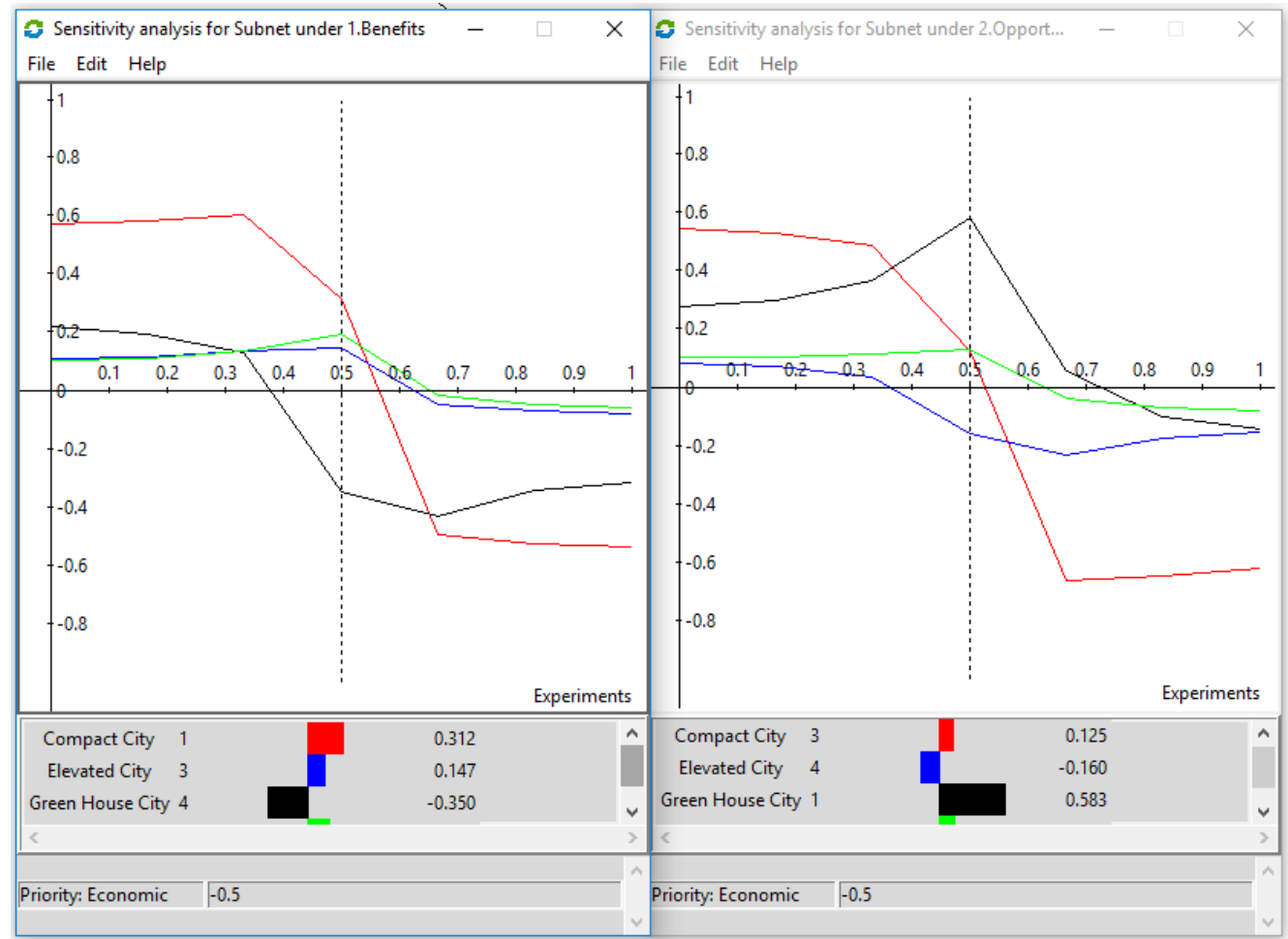

(a)

(b)

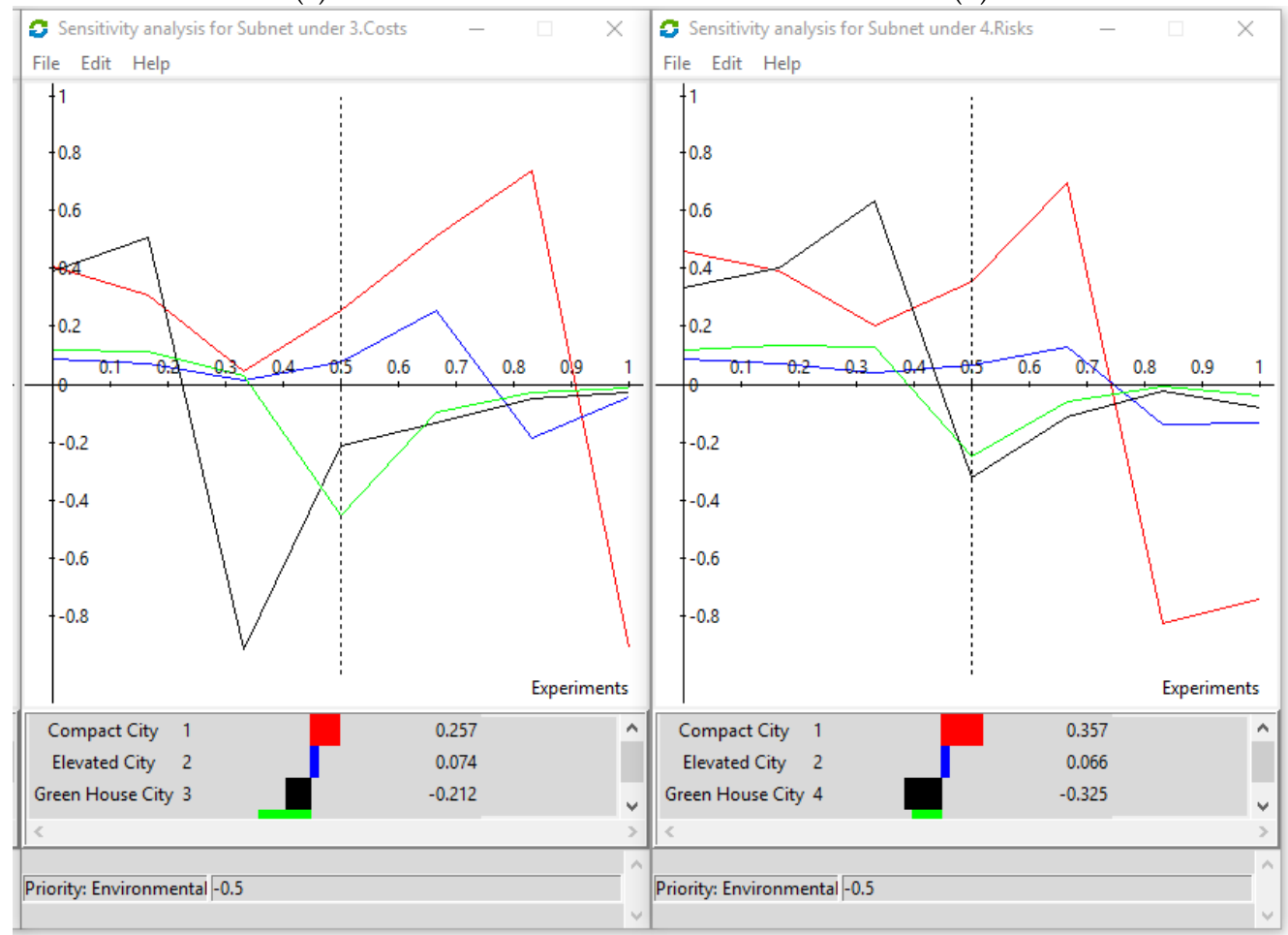

(c)

(d)

Figure 5. Results of sensitivity analysis: Benefits (a); Opportunities (b); Costs (c); Risks (d).

\section{Ranking Today's European Cities}

In today's Europe, many different kinds of cities coexist: cities that merge two continents like Istanbul, flat or hill cities like Paris or Rome, new three-dimensional sky scraper cities like London, water cities like Venice or Amsterdam, cold weather cities existing in the Scandinavian peninsula, cities 
in the mountains like Andorra la Vella (the highest mountain capital city in Europe with $1.023 \mathrm{~m}$ ), medieval cities like Florence or Prague, and fully enclosed cities like compact cities.

Some known cities in Europe have been selected for this case study, where each city has some unique features that make each one noticeable different from the other. Cities are chosen for particular reasons which make them alternatives among them: Paris is the largest and widest of the European capital cities, Rome is a flat/hill European capital city, London is the European capital city characterized by three-dimensions, Andorra la Vella is the highest European capital city, Amsterdam is the unique European capital city on the water, Copenhagen is a green European capital city and, finally, the compact city as the best city for the future. Figure 6 shows some images of the compact city model.

The ranking of European cities is carried out by the B.O.C.R. model. Benefits and costs are referred to in the present time, opportunities and risks will be referred to in the future.

The criteria used for the B.O.C.R. model are mainly taken from international literature related to city ranking [53]. In addition to tangible criteria taken from literature, other intangible criteria are included in the case study.

Through pairwise comparisons, the criteria priorities are determined and, then, the judgment about the seven selected cities by comparing them on each criterion separately and finally weight or multiply the priorities of the alternatives by the importance or priorities of the criteria and add to determine the best city.

Prefixed priorities and data are based on personal experiences and critical opinions, considering also the specific criticalities of European cities. Quantitative or qualitative information for the judgments are taken from the Arcadis report on "Sustainable Cities Index 2016" [36].

The pairwise comparison judgments are entered by comparing a criterion listed on the left of the table with another listed at the top. A criterion compared with itself is always assigned the value one. The values $3,5,7$, and 9 correspond to the following verbal judgments of the comparisons of elements on the left over those at the top: 'moderately more dominant', 'strongly more dominant', 'very strongly more dominant', and 'extremely more dominant' (with the values $2,4,6$, and 8 for compromise between the previous values). Instead, the reciprocal values $(1 / 3,1 / 5,1 / 7,1 / 9)$ are automatically inserted when the element on the left does not dominate, but it is dominated by the element at the top of the table [1].

The priorities are obtained by raising the matrix to a large power to capture all the interactions, adding the entries in each row and dividing by the total sum of the rows. It is mathematically demonstrated that it is necessary to use this scale to get meaningful results in practice. It represents the normal range of human sensitivity to phenomena that are homogeneous.

Figures 7-10 show the structures of the B.O.C.R. model. The chosen criteria for the judgement on cities are always inserted at the second level of the hierarchy, while the candidate cities (or the alternatives of decision making) are at the third level.

For brevity of discussion, criteria and priorities are fully listed in Table 6:

\section{Benefits model}

- Social subnet. For this subnet, the element 'public services' has the highest global priority.

- Environmental and ecology subnet. For this subnet, the element 'pollution' has the highest global priority.

- Economic subnet. For this subnet, the element 'energy consumption' has the highest global priority.

- Security subnet. For this subnet, 'crime rate' is the only element considered.

- For the benefits model, the compact city has the highest benefits, followed by Copenhagen and Amsterdam (see Table 7).

\section{Opportunities model}

- Social subnet. For this subnet, 'leisure time' is the only element considered. 
- Technological subnet. For this subnet, the element 'measures of innovation' has the highest global priority.

- Economic subnet. For this subnet, the element 'job creation' has the highest global priority.

- For the opportunities model, London presents the greatest opportunities followed by Paris (see Table 7).

\section{Costs model}

- Environmental subnet. For this subnet, 'loosing green' is the only element considered.

- Economic subnet. For this subnet, the element 'waste disposal' has the highest global priority.

- Social subnet. For this subnet, the element 'heritage cost' has the highest global priority.

- For the costs model, Rome presents the highest costs followed by Amsterdam (see Table 7).

\section{Risks model}

- Technological subnet. For this subnet, the element 'uncertainty about technological feasibilities' has the highest global priority.

- Environment and ecology subnet. For this subnet, the element 'unacceptable losses of life' has the highest global priority.

- Economic subnet. For this subnet, the element 'risk in maintaining the public services' has the highest global priority.

- Social subnet. For this subnet, the element 'population increase and Immigration' has the highest global priority.

- For the Risks model, Rome presents the highest risks in absolute (see Table 7).

In Table 7 the overall output about European cities is presented.

For the long-term and short-term scenarios, the overall synthesized priorities for the alternatives are reported in Figures 11 and 12. Results of multiplicative formula (Figure 11) and additive formula (Figure 12) highlight always the compact city as the best choice followed by Copenhagen.

As already mentioned in the previous paragraph, the additive formula is the best option for to interpret the best long-term alternative, the multiplicative formula is the more suitable solution to identify the best short-term alternative.

In the case study, the ranking of first two cities are the same for both methods of synthesizing although this is not necessarily true in general. In the short-term, Copenhagen is second, Andorra is the third, and Amsterdam comes in fourth. To further explore our outcome, we can show the sensitivity analysis in the short-term scenario respect to costs and risks. If risks become more important (after 0.50), the compact city, Copenhagen, and Andorra maintain still, respectively, the first, second, and third place (see Figure 13). If costs become more important (after 0.50), the compact city, Amsterdam, and Copenhagen are, respectively, at the first, second, and third place (see Figure 13). 


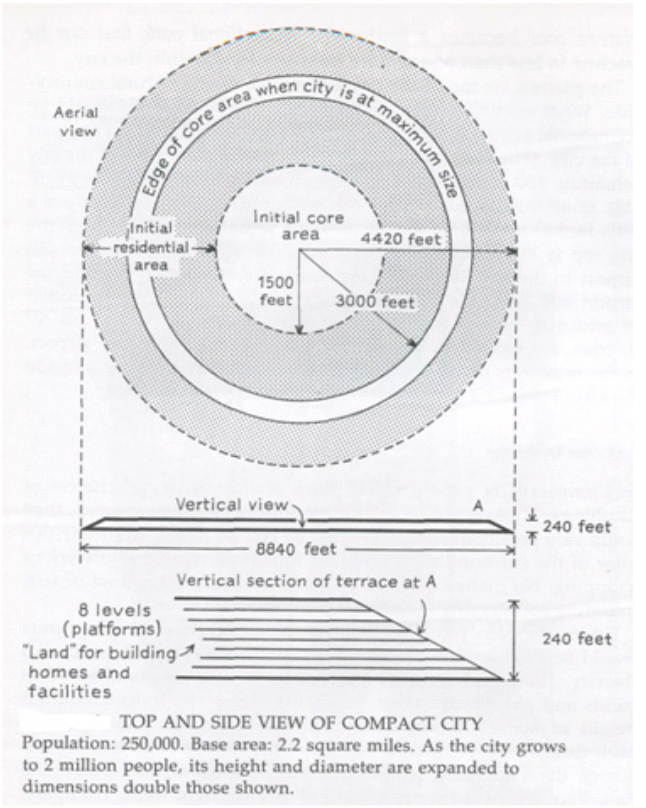

(a)

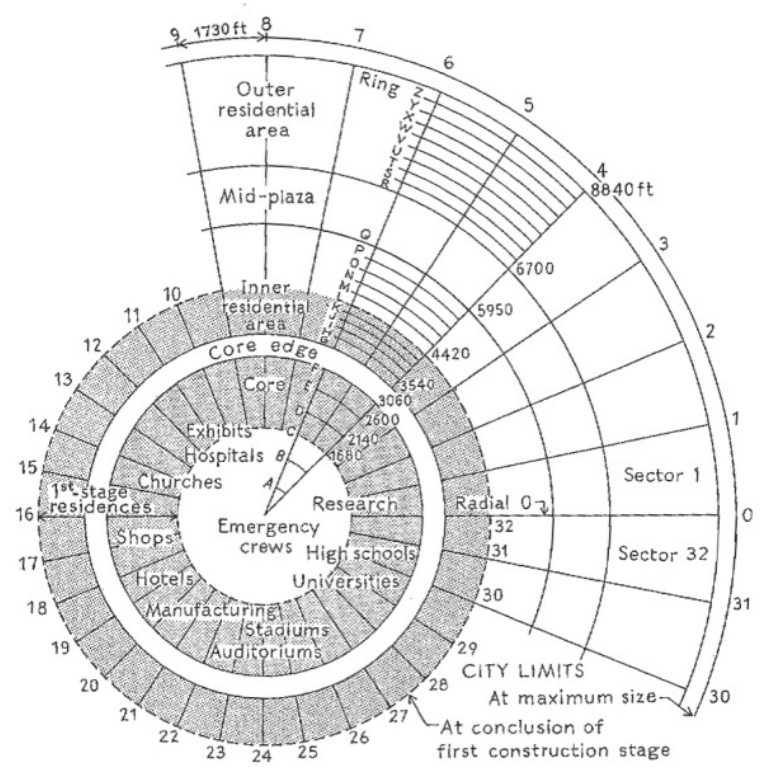

(b)

Figure 6. Compact city model: top and side view (a); typical plan (b) [1].

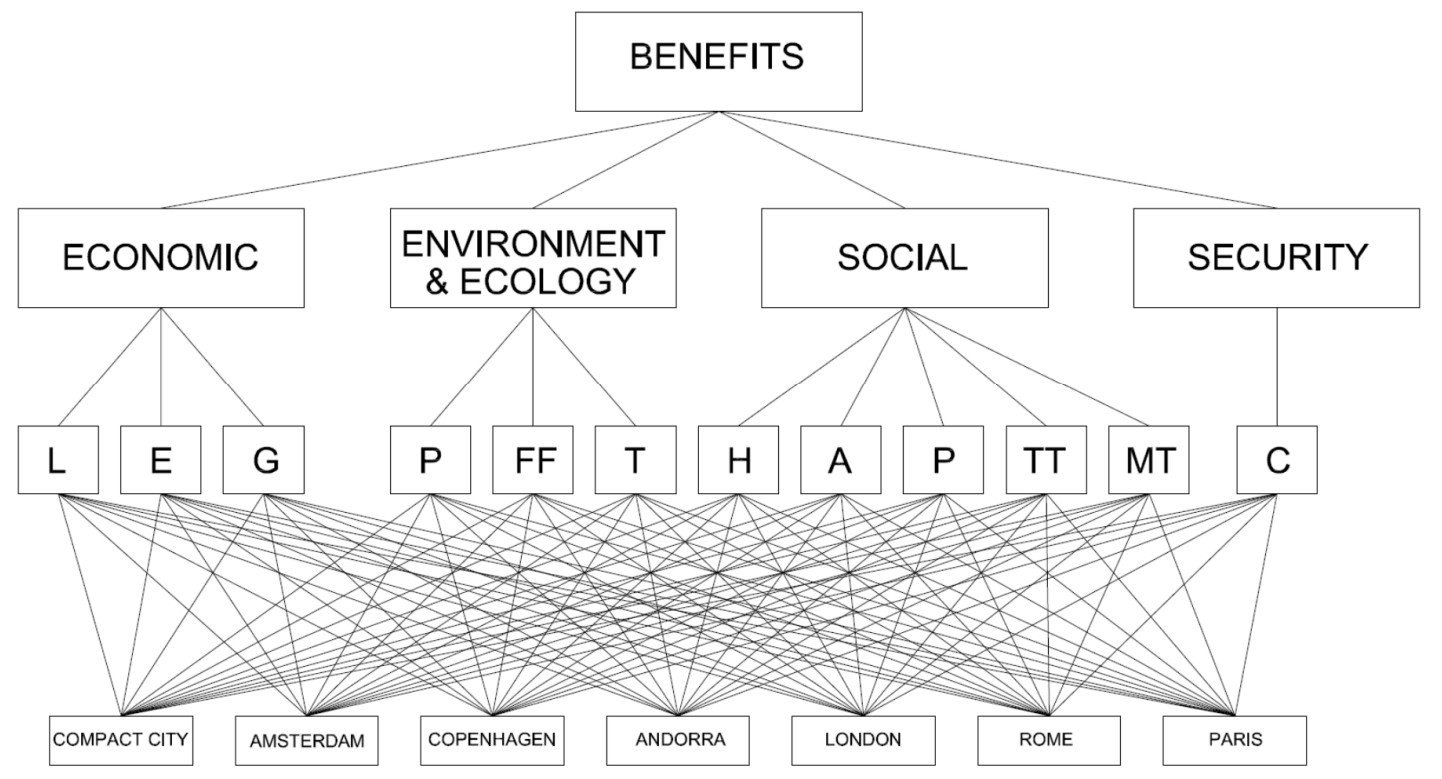

Figure 7. The best European city benefits hierarchy. 


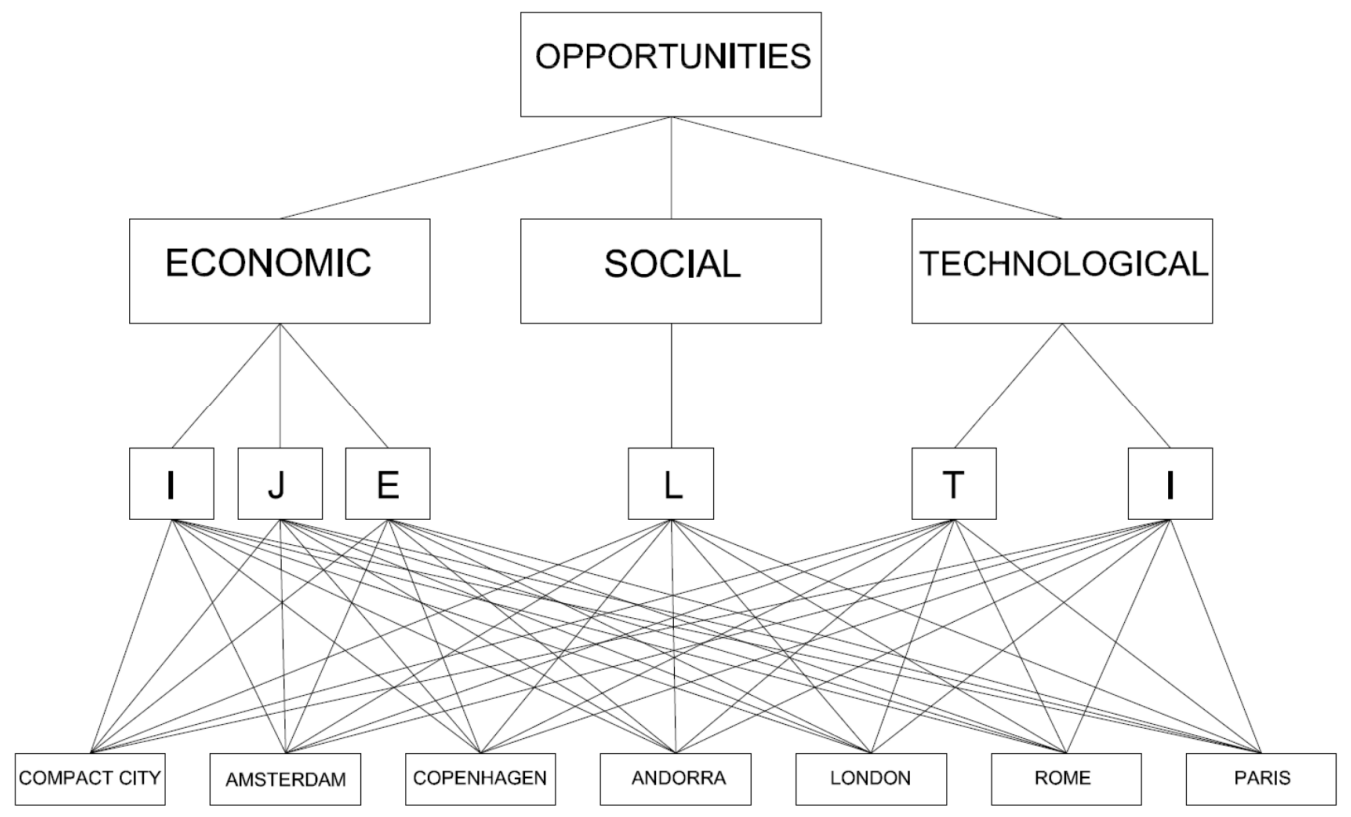

Figure 8. The best European city opportunities hierarchy.

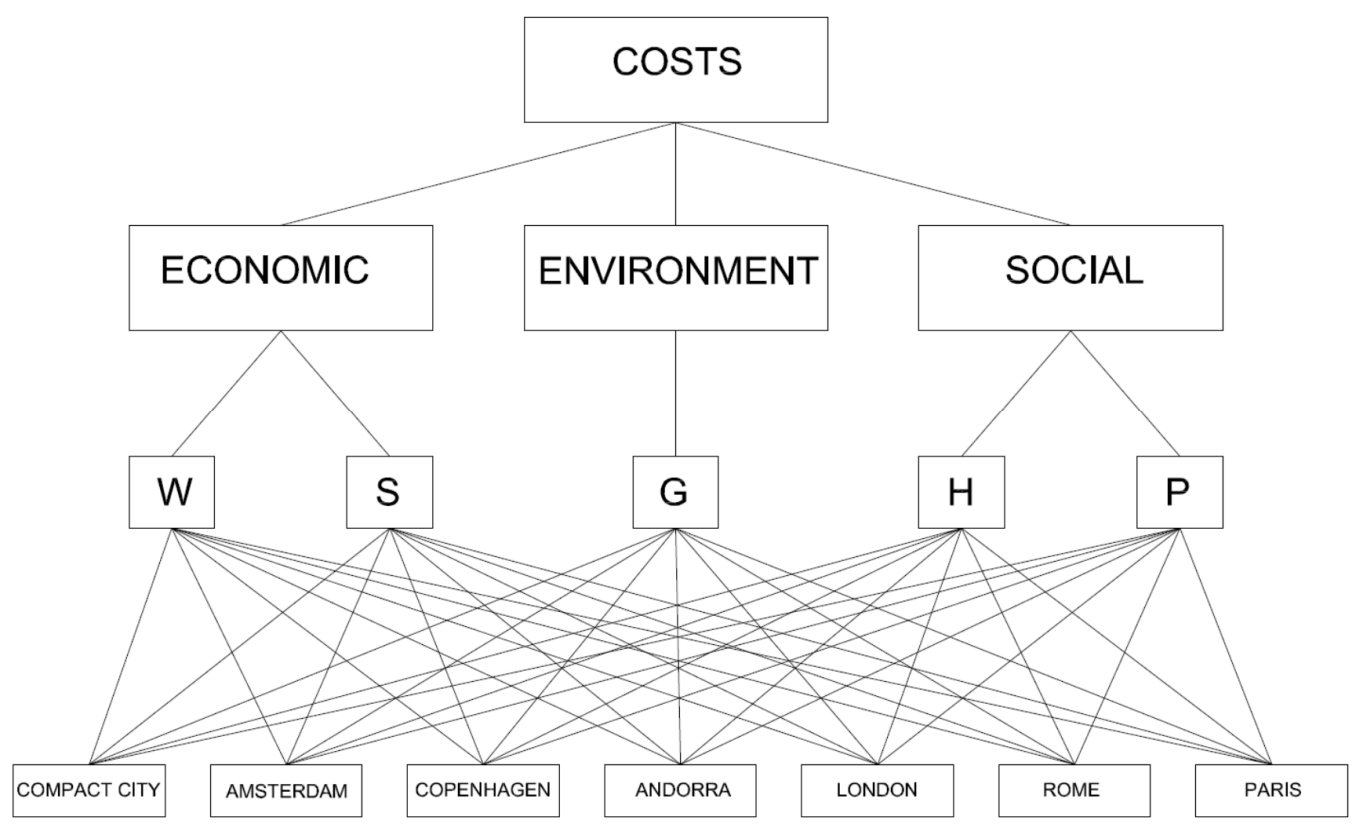

Figure 9. The best European city costs hierarchy. 


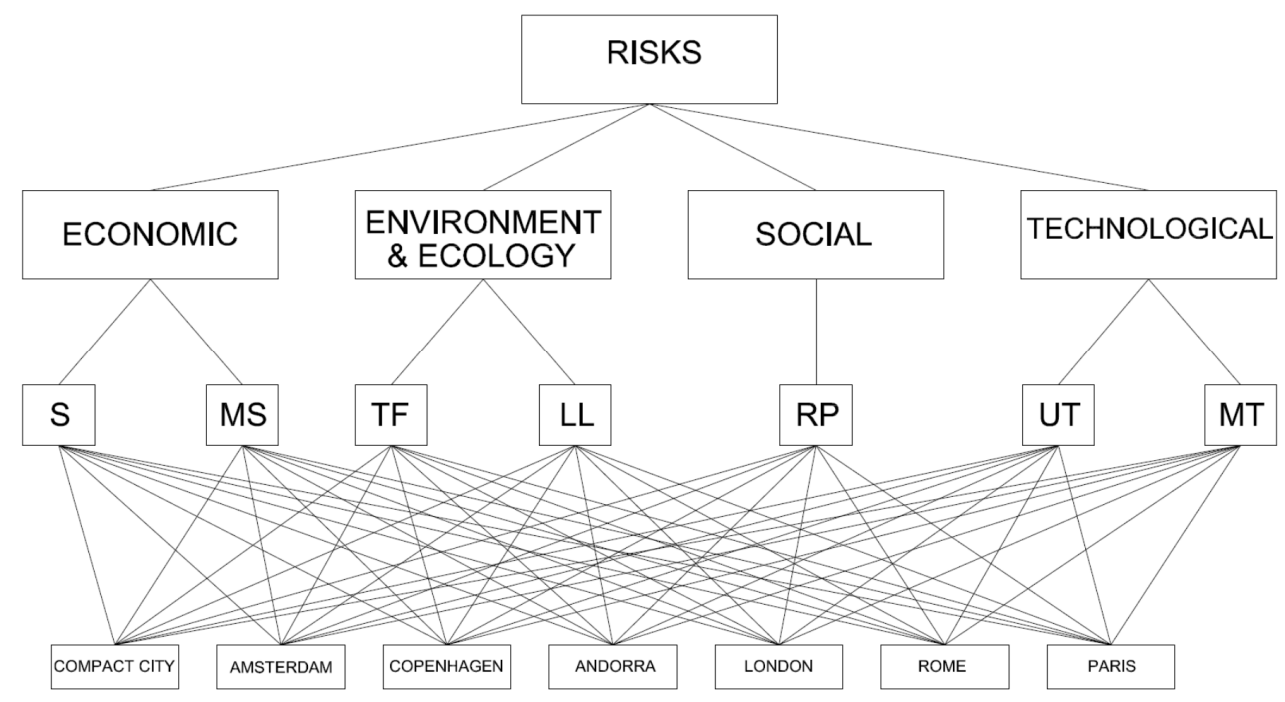

Figure 10. The best European city risks hierarchy.

Table 6. B.O.C.R. criteria and priorities.

\begin{tabular}{|c|c|c|c|c|c|}
\hline \multicolumn{2}{|c|}{ BENEFITS (0.26) } & \multirow{2}{*}{$\begin{array}{c}\text { Priority } \\
0.009\end{array}$} & \multicolumn{2}{|c|}{ OPPORTUNITIES (0.31) } & Priority \\
\hline \multirow{3}{*}{ Economic (0.16) } & $\begin{array}{l}\text { L-Living expenses } \\
(0.219)\end{array}$ & & \multirow{3}{*}{$\begin{array}{l}\text { Economic } \\
\quad(0.43)\end{array}$} & $\begin{array}{l}\text { I-Improving the } \\
\text { budget }(0.372)\end{array}$ & 0.050 \\
\hline & $\begin{array}{c}\text { E-Energy } \\
\text { consumption }(0.485)\end{array}$ & 0.020 & & J-Job creation (0.421) & 0.056 \\
\hline & $\begin{array}{l}\text { G-Per-capita income } \\
\text { growth }(0.296)\end{array}$ & 0.012 & & $\begin{array}{c}\text { E-Expandability } \\
(0.207)\end{array}$ & 0.028 \\
\hline \multirow{4}{*}{$\begin{array}{l}\text { Environment and } \\
\text { ecology }(0.44)\end{array}$} & P-Pollution (0.426) & 0.049 & Social (0.15) & $\begin{array}{c}\text { L-Leisure time } \\
(1.000)\end{array}$ & 0.046 \\
\hline & $\mathrm{T}$-Traffic $(0.163)$ & 0.019 & \multirow{2}{*}{$\begin{array}{c}\text { Technological } \\
(0.42)\end{array}$} & $\begin{array}{c}\text { T-Better } \\
\text { technological } \\
\text { advances }(0.485)\end{array}$ & 0.062 \\
\hline & \multirow{2}{*}{$\begin{array}{l}\text { FF_-Flora and fauna } \\
(0.411)\end{array}$} & \multirow[t]{2}{*}{0.047} & & $\begin{array}{l}\text { M-Measures of } \\
\text { innovation }(0.515)\end{array}$ & 0.066 \\
\hline & & & & TS $(0.21)$ & Priority \\
\hline Security (0.15) & $\mathrm{C}$-Crime rate $(1.000)$ & 0.039 & Fconomic (0 5) & $\begin{array}{c}\text { W-Waste disposal } \\
(0.582)\end{array}$ & 0.061 \\
\hline \multirow{5}{*}{ Social (0.25) } & $\mathrm{H}-$ Housing $(0.232)$ & 0.015 & Econotitic (0.5) & $\begin{array}{c}\text { S-Security cost } \\
(0.418)\end{array}$ & 0.044 \\
\hline & $\begin{array}{c}\text { A-Accessibility of } \\
\text { health services }(0.262)\end{array}$ & 0.017 & \multirow{2}{*}{ Social (0.25) } & $\begin{array}{c}\mathrm{H}-\text { Heritage cost } \\
(0.627)\end{array}$ & 0.033 \\
\hline & $\begin{array}{c}\text { P-Public services } \\
(0.326)\end{array}$ & 0.021 & & $\begin{array}{c}\text { P-Psychological cost } \\
(0.373)\end{array}$ & 0.020 \\
\hline & $\begin{array}{l}\text { TT-Time spent in } \\
\text { travelling }(0.061)\end{array}$ & 0.004 & \multirow{2}{*}{$\begin{array}{l}\text { Environment } \\
\quad(0.25)\end{array}$} & \multirow[t]{2}{*}{$\begin{array}{l}\mathrm{G} \text {-Loosing green } \\
(1.000)\end{array}$} & \multirow[t]{2}{*}{0.053} \\
\hline & $\begin{array}{c}\text { MT-Metro Areas } \\
(0.119)\end{array}$ & 0.008 & & & \\
\hline \multicolumn{2}{|c|}{ RISKS (0.22) } & Priority & \multicolumn{2}{|c|}{ RISKS (0.22) } & Priority \\
\hline \multirow[b]{2}{*}{ Economic (0.45) } & $\begin{array}{c}\text { S-Economic } \\
\text { sustainability }(0.373)\end{array}$ & 0.037 & \multirow[b]{2}{*}{ Social (0.13) } & \multirow{2}{*}{$\begin{array}{c}\text { RP_Population } \\
\text { increase and } \\
\text { Immigration }(1.000)\end{array}$} & \multirow[b]{2}{*}{0.029} \\
\hline & $\begin{array}{c}\text { MS-Risk in } \\
\text { maintaining the } \\
\text { public services }(0.627)\end{array}$ & 0.062 & & & \\
\hline \multirow{2}{*}{$\begin{array}{l}\text { Environment and } \\
\text { ecology }(0.14)\end{array}$} & $\begin{array}{l}\text { TF-Threat to flora } \\
\text { and fauna }(0.415)\end{array}$ & 0.013 & \multirow{2}{*}{$\begin{array}{c}\text { Technological } \\
(0.28)\end{array}$} & $\begin{array}{l}\text { UT-Uncertainty } \\
\text { about technological } \\
\text { feasibilities }(0.742)\end{array}$ & 0.046 \\
\hline & $\begin{array}{l}\text { LL-Unacceptable } \\
\text { losses of life }(0.585)\end{array}$ & 0.018 & & $\begin{array}{c}\text { MT-Misuse of } \\
\text { technology }(0.258)\end{array}$ & 0.016 \\
\hline
\end{tabular}


Table 7. Overall output.

\begin{tabular}{ccccc}
\hline City & Benefits & Opportunities & Costs & Risks \\
\hline Compact City & 0.270 & 0.129 & 0.046 & 0.041 \\
Amsterdam & 0.170 & 0.181 & 0.207 & 0.132 \\
Copenhagen & 0.199 & 0.122 & 0.055 & 0.065 \\
Andorra & 0.188 & 0.027 & 0.042 & 0.056 \\
London & 0.069 & 0.224 & 0.140 & 0.245 \\
Rome & 0.041 & 0.134 & 0.347 & 0.261 \\
Paris & 0.063 & 0.183 & 0.163 & 0.200 \\
\hline
\end{tabular}

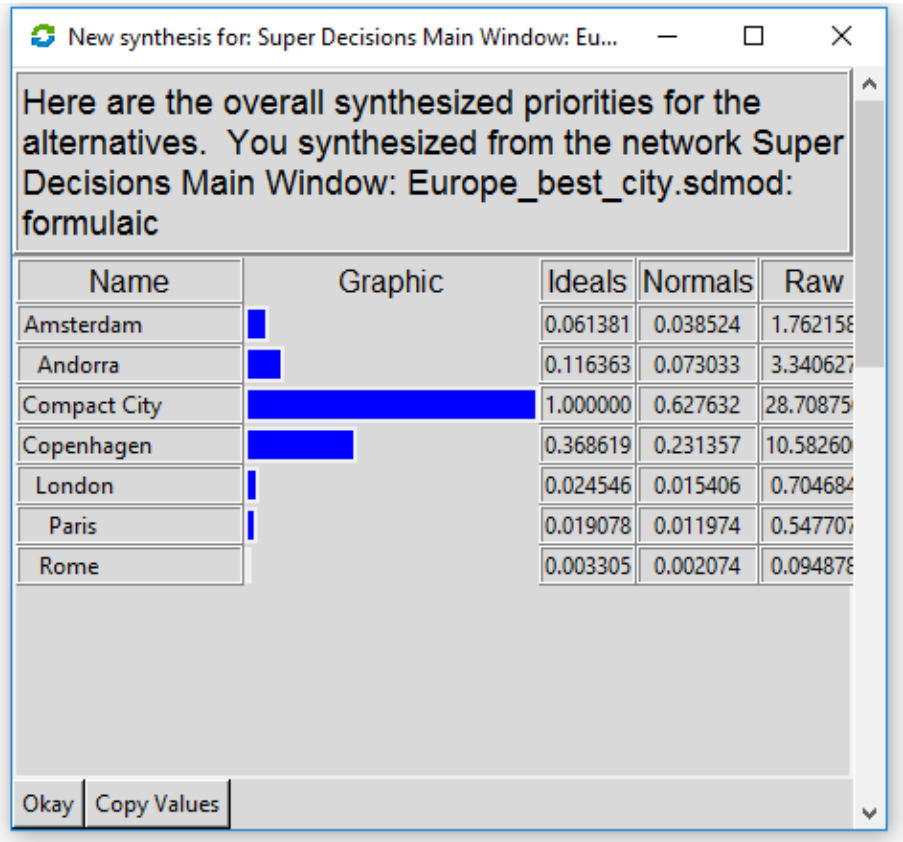

Figure 11. Results on best European city in the short-term (multiplicative formula).

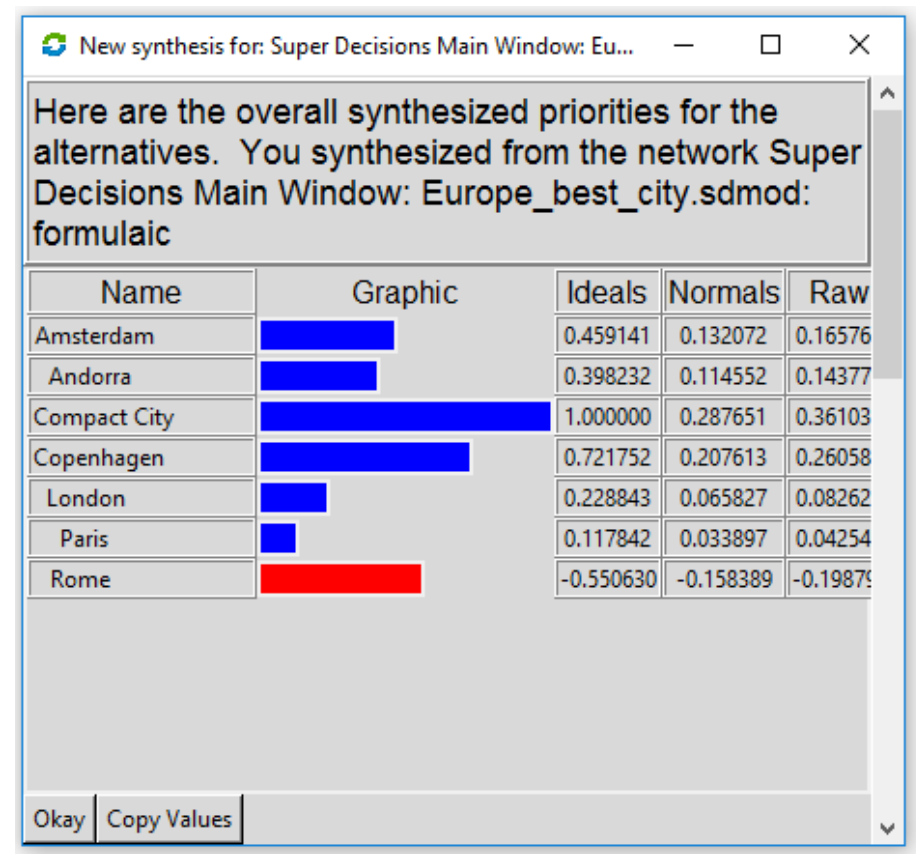

Figure 12. Results on best European city in the long-term (additive formula). 


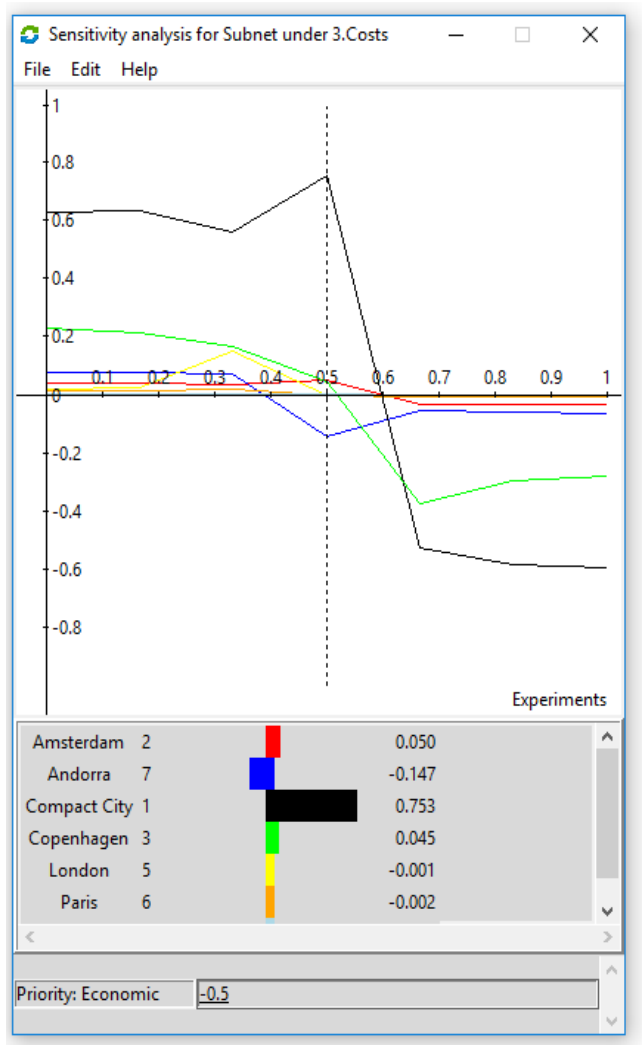

(a)

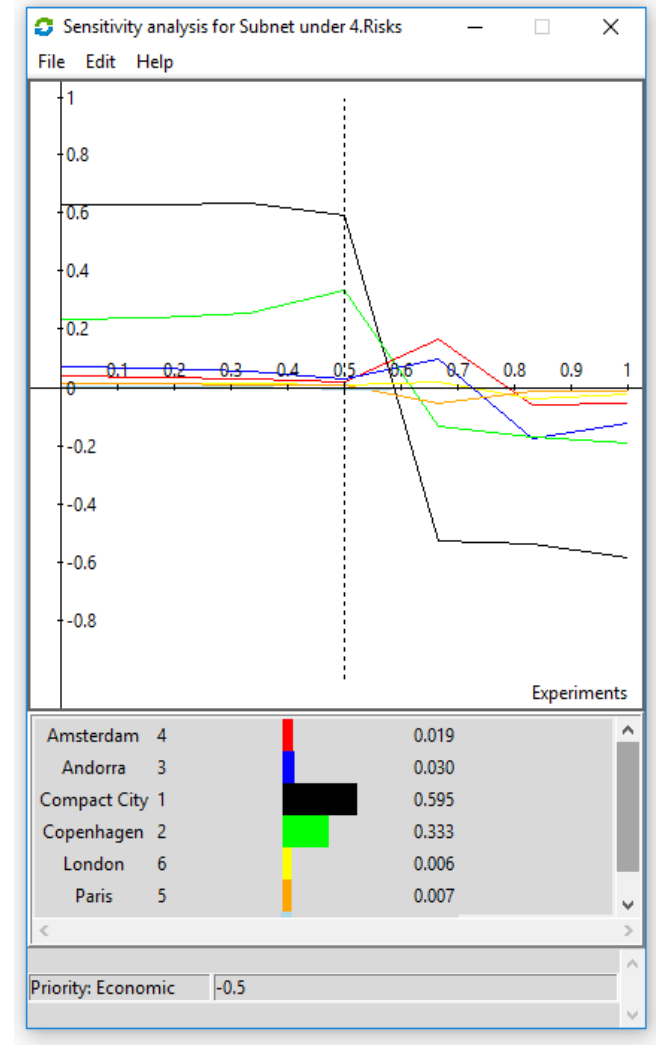

(b)

Figure 13. Sensitivity analysis with respect to costs (a) and risks (b).

\section{Concluding Remarks}

Many cities have piecemeal forms. Future challenges for European cities will need to include rethinking design and urban planning.

The compact city model is the best solution for design and urban planning, taking into account of urban sprawl, building transformations, and economic effects on environment. Today, there are only few alternatives, few cities have greater awareness and attention to energy consumption, environmental sustainability, quality of public services, and social assistance.

The future of cities will always involve more complex situations requiring a holistic approach for policy decisions. In this sense, the modern theories of decision making can help to make rational choices in building cities.

Author Contributions: This paper is to be attributed in equal parts to the authors.

Conflicts of Interest: The authors declare no conflict of interest.

\section{References}

1. Saaty, T.L. Compact City: The Next Urban Evolution in Response to Climate Change; RWS Publications: Pittsburgh, PA, USA, 2013.

2. Del Giudice, V.; De Paola, P.; Torrieri, F.; Pagliara, F.; Nijkamp, P. A decision support system for real estate investment choice, Scienze Regionali. Ital. J. Reg. Sci. 2010. Available online: http://dare.ubvu.vu.nl/ bitstream/handle/1871/15279/20090010.pdf?sequence=2 (accessed on 13 June 2017).

3. McKinsey Global Institute. Available online: www.mckinsey.com (accessed on 13 June 2017).

4. Greenpeace International. Available online: www.greenpeace.org (accessed on 13 June 2017).

5. Intergovernmental Panel on Climate Change. Available online: www.ipcc.ch (accessed on 13 June 2017). 
6. Del Giudice, V.; De Paola, P.; Forte, F. The appraisal of office towers in bilateral monopoly's market: Evidence from application of Newton's physical laws to the Directional Centre of Naples. Int. J. Appl. Eng. Res. 2016, 11, 9455-9459.

7. Del Giudice, V.; Manganelli, B.; De Paola, P. Depreciation methods for firm's assets. In Lecture Notes in Computer Science; Springer: Berlin, Germany, 2016; pp. 214-227.

8. Del Giudice, V.; De Paola, P.; Manganelli, B.; Forte, F. The monetary valuation of environmental externalities through the analysis of real estate prices. Sustainability 2017, 9, 229. [CrossRef]

9. Del Giudice, V.; De Paola, P.; Cantisani, G.B. Rough Set Theory for real estate appraisals: An application to Directional District of Naples. Buildings 2017, 7, 12. [CrossRef]

10. Del Giudice, V.; De Paola, P.; Cantisani, G.B. Valuation of real estate investments through Fuzzy Logic. Buildings 2017, 7, 26. [CrossRef]

11. Del Giudice, V.; De Paola, P.; Forte, F. Using Genetic Algorithms for Real Estate Appraisal. Buildings 2017, 7, 31. [CrossRef]

12. Del Giudice, V.; Manganelli, B.; De Paola, P. Hedonic analysis of housing sales prices with semiparametric methods. Int. J. Agric. Environ. Inf. Syst. 2017, 8, 65-77. [CrossRef]

13. European Commission, Joint Programming Initiative (JPI). Available online: www.jpi.urbaneurope.eu (accessed on 13 June 2017).

14. ERA Portal Austria, the Knowledge-Sharing Platform. Available online: www.era.gv.at (accessed on 13 June 2017).

15. Wikipedia. Available online: www.wikipedia.org (accessed on 13 June 2017).

16. Burton, E.; Jenks, M.; Williams, K. The Compact City: A Sustainable Urban form; Spon Press-Taylor \& Francis: London, UK, 2005.

17. Burgess, R.; Jenks, M. Compact Cities: Sustainable Urban Forms for Developing Countries; Spon Press-Taylor \& Francis Group: London, UK, 2004.

18. Holden, E.; Norland, I.T. Three Challenges for the Compact City as a Sustainable Urban Form: Household Consumption of Energy and Transport in Eight Residential Areas in the Greater Oslo Region. In Urban Studies; Sage Publishing: New York, NY, USA, 2005; Volume 42, pp. 2145-2166.

19. Basiago, A.D. The search for the sustainable city in 20th century urban planning. Environmentalist 1996, 16, 135-155. [CrossRef]

20. Howard, E. Garden Cities of Tomorrow (1946 edition); Faber and Faber: London, UK, 1902.

21. Geddes, P. Cities in Evolution (1948 edition); Williams and Norgate: London, UK, 1915.

22. Wright, F.L. Broadacre City: A new community plan. Archit. Rec. 1935, 77, 243-254.

23. Mumford, L. The Culture of Cities; Harcourt, Brace and Co.: New York, NY, USA, 1938.

24. Mumford, L. The City in History; Harcourt, Brace and World, Inc.: New York, NY, USA, 1961.

25. McHarg, I. Design With Nature; Natural History Press: Philadelphia, PA, USA, 1969.

26. Mollison, B.; Holmgren, D. Permaculture One: A Perennial Agricultural System for Human Settlements; Tagari Publications: New South Wales, Australia, 1979.

27. Corbett, M.; Corbett, J. Energy and the Human Environment, College of Human Ecology Monograph Series; Michigan State University: East Lansing, MI, USA, 1984; Volume 103, pp. 1-11.

28. Commission of the European Communities (CEC). Green Paper on the Urban Environment; CEC: Brussels, Belgium, 1990.

29. Nash, R. Island Civilisation; Wild Earth, Winter: Gold Coast, Australia, 1991.

30. Girardet, H. Cities: New Directions for Sustainable Urban Living; Gaia Books: London, UK, 1992.

31. McDonough, W. The Hannover Principles; William McDonough: New York, NY, USA, 1992.

32. Canfield, C. Cerro Gordo: Exploring symbiotic community. Cerro Gordo Town Forum 1993, 20, $15-17$.

33. Calthorpe, P. The Next American Metropolis: Ecology, Community and the American Dream; Princeton Architectural Press: New York, NY, USA, 1993.

34. McDonald, M. Los Osos, California: A Proposal for a Sustainable Community Within a Sustainable Watershed. Available online: http:/ / digitalcommons.calpoly.edu/cgi/viewcontent.cgi?article=1002\&context=arch_fac (accessed on 13 June 2017).

35. Lyle, J.T. Designing green infrastructure. In The Sustainability Project, Designing for Sustainable Communities; AIA: Santa Barbara, CA, USA, 1994.

36. Sustainable Cities Index 2016. Available online: www.arcadis.com (accessed on 13 June 2017). 
37. Cohen Boyd, Smart Cities Wheel. Available online: www.fastcoexist.com (accessed on 13 June 2017).

38. Cities in Motion Index (CIMI). IESE Center for Globalization and Strategy-University of Navarra. 2016. Available online: www.forbes.com (accessed on 13 June 2017).

39. Dantzig, G.B.; Saaty, T.L. Compact City: A Plan for a Liveable Urban Environment; W.H. Freeman and Company: San Francisco, CA, USA, 1973.

40. Arifwidodo, S.D.; Perera, R. Quality of Life and Compact Development Policies in Bandung Indonesia. Appl. Res. Qual. Life 2010, 6, 159-179. [CrossRef]

41. Eco-Compact City Network (ECCN). Available online: www.ecocompactcity.org (accessed on 13 June 2017).

42. Saaty, T.L. Axiomatic Foundation of the Analytic hierarchy process. Manag. Sci. 1986, 32, 841-855. [CrossRef]

43. Saaty, T.L.; Vargas, L.G. Decision Making with the Analytic network process: Economic, Political, Social and Technological Applications with benefits, Opportunities, Costs and Risks. In Springer's International Series; Springer: Berlin, Germany, 2006.

44. Saaty, T.L. Theory and Applications of the Analytic network process; RWS Publications: Pittsburgh, PA, USA, 2005.

45. Saaty, T.L. Decision Making with the Analytic hierarchy process. Int. J. Serv. Sci. 2008, 1, 83-89. [CrossRef]

46. Vidal, L.A.; Marle, F.; Bocquet, J.C. Using a Delphi process and the Analytic hierarchy process (AHP) to evaluate the complexity of projects. Expert Syst. Appl. 2011, 38, 5388-5405. [CrossRef]

47. Vidal, L.A.; Marle, F.; Bocquet, J.C. Measuring project complexity using the Analytic hierarchy process. Int. J. Proj. Manag. 2011, 29, 718-727. [CrossRef]

48. Morano, P.; Locurcio, M.; Tajani, F. Cultural Heritage Valorization: An application of AHP for the choice of the highest and best use. Procedia Soc. Behav. Sci. 2016, 223, 952-959. [CrossRef]

49. Guarini, M.R.; D’Addabbo, N.; Morano, P.; Tajani, F. Multi-Criteria Analysis in compound decision processes: The AHP and the architectural competition for the Chamber of Deputies in Rome (Italy). Buildings 2017, 7, 38. [CrossRef]

50. Ishizaka, A.; Labib, A. Review of the main developments in the Analytic hierarchy process. Expert Syst. Appl. 2011, 38, 14336-14345. [CrossRef]

51. Sipahi, S.; Timor, M. The Analytic hierarchy process and Analytic network process: An overview of applications. Manag. Decis. 2010, 48, 775-808. [CrossRef]

52. Subramanian, N.; Ramanathan, R. A review of applications of Analytic hierarchy process in operations management. Int. J. Prod. Econ. 2012, 138, 215-241. [CrossRef]

53. Sperling, B.; Sander, P. Cities Ranked E Rated: More than 400 Metropolitan Areas Evaluated in the U.S. and Canada; John Wiley \& Sons: Hoboken, NJ, USA, 2007. 